\title{
Evaluation of skin graft take following post-burn raw area in normovolaemic anaemia
}

\author{
Pawan Agarwal, Brijesh Prajapati, D. Sharma \\ Plastic Surgery Unit, Department of Surgery, N.S.C.B. Government Medical College, Jabalpur-482 003, MP, India.
}

Address for correspondence: Dr. Pawan Agarwal, 292/293 Napier Town, Jabalpur- 482 001, MP, India.

E-mail: drpawanagarwal@yahoo.com

\section{ABSTRACT}

Background: Traditional wisdom is that wound healing is directly related to haemoglobin level in the blood; therefore blood transfusion is given in anaemic patients to raise the haemoglobin level for better wound healing. Methods: Evaluation of wound healing in the form of split thickness skin graft take was done in 35 normovolaemic anaemic patients (haemoglobin level of $<10 \mathrm{gm} / \mathrm{dl}$ ) and compared with control group (patients with haemoglobin level of 10 or $>10 \mathrm{gm} / \mathrm{dl}$ ). Results: There was no statistically significant difference in mean graft take between the two groups. Conclusion: It is not mandatory to keep haemoglobin level at or $>10 \mathrm{~g} / \mathrm{dL}$ or PCV value at or $>30 \%$ for skin graft take, as mild to moderate anaemia per se does not cause any deleterious effect on wound healing; provided perfusion is maintained by adequate circulatory volume. Prophylactic transfusion to increase the oxygen carrying capacity of the blood for the purpose of wound healing is not indicated in asymptomatic normovolemic anaemic patients (with haemoglobin levels greater than $6 \mathrm{~g} / \mathrm{dL}$ ) without significant cardiovascular or pulmonary disease.

\section{KEY WORDS}

Anaemia, skin graft take, wound healing

\section{INTRODUCTION}

$t$ is a well-known fact that sufficient oxygen supply and avoidance of wound infection is critical to the healing process as ischemic tissues heal poorly and get easily infected. Animal experimentations have shown that arterial hypoxia retards healing by reducing wound tensile strength, therefore anaemia seems to be detrimental to healing. ${ }^{[1]}$ Previous theory in the last decade has been that haemoglobin level should be maintained above $10 \mathrm{~g} / \mathrm{dL}$ to promote wound healing. ${ }^{[2,3]}$ As a result, some physicians and surgeons have been promoting blood transfusion to raise the haemoglobin level for better wound healing. The decision to transfuse blood is guided largely by the haemoglobin concentration of the patient, and as a rule if the patient's haemoglobin or haematocrit drops below $10 \mathrm{~g} / \mathrm{dL}$ or $30 \%$ respectively, prophylactic transfusions are usually administered. This empirical, dogmatic approach to blood transfusion was based on the concept that the riskbenefit ratio favoured transfusion in anaemic patients. Today, this principle no longer appears valid since it has become increasingly clear that blood transfusion, although potentially beneficial, is not without risk. ${ }^{[4]} \mathrm{A}$ strategy commonly employed by surgeons and anaesthesiologists is to request more units of blood than they anticipate transfusing intraoperatively to provide a margin of safety in the event of unexpected haemorrhage. The ready availability of one or two cross-matched units of blood in the operating room may even serve as a stimulus 
for unnecessary blood transfusions. It is important to re-evaluate the blood transfusion policy because of an inherent risk of transfusion reaction, transmission of many viral, bacterial and parasitic diseases, increased workload over blood banks and increased cost of patient care.

Blood transfusions have non-specific immuno-suppressive properties that render recipients susceptible to infectious complications and retard wound healing. ${ }^{[5,6]}$ Other strategies to reduce intraoperative blood loss include the use of topical thrombin and epinephrine, extremity tourniquets, acute normovolaemic hemodilution, and hypotensive anaesthesia. ${ }^{[7]}$ The present study was conducted to evaluate the state of wound healing vis-à-vis split skin graft take in normovolaemic anaemic patients.

\section{MATERIAL AND METHODS}

Before starting the study, institutional ethical committee approval was taken. Seventy consecutive patients following post-burn raw area, due for split thickness grafting, were randomised prospectively irrespective of age, sex, weight and nutritional status. Patients with thermal burn $>25 \%$ were excluded from the study. Patients with known history of diabetes mellitus, hypertension, nephritis, jaundice, bronchial asthma, tuberculosis, malignancy and history of steroid administration were also excluded. On admission, all the burn patients were treated with a standard regimen consist of fluid resuscitation, antibiotics, wound management and care of nutrition till their wound either healed or granulated. During this period blood transfusions if necessary were given. After the wound granulated no patients were given blood transfusion. Patients were divided into study groups $(\mathrm{n}=35)$ with haemoglobin $<10 \mathrm{~g} /$ $\mathrm{dL}$, haematocrit $<30 \%$ and serum protein $<6 \mathrm{gm} \%$ and control group $(\mathrm{n}=35)$ with haemoglobin level $=$ or $>$ $10 \mathrm{~g} / \mathrm{dL}$, haematocrit $=$ or $>30 \%$ and serum protein $=$ or $>6$ gm\% [Tables 1, 2]. After debridement of recipient site, split thickness skin graft was harvested from thigh and applied on the raw area. The average raw area covered with skin graft in study group was $7 \%$ and in control group was $8 \%$. Assessment of skin graft take was done on $10^{\text {th }}$ postoperative day.

Haemoglobin and haematocrit were again measured on $1 \mathrm{st}$ and on 10th postoperative day. Results were assessed clinically by reviewers who were blinded to the haemoglobin and haematocrit levels of the patients. Statistical analysis was done using Chi Square test and level of significance was taken as $<0.005$. Blood transfusion was avoided and only colloids are administered when it became mandatory to make the patients hemodynamically stable.

\section{RESULTS}

The youngest patient was five years old and the oldest was 60 . The mean preoperative haemoglobin and haematocrit level in the study group was $8.5 \mathrm{~g} / \mathrm{dL}$ and $25 \%$ respectively. The mean $1^{\text {st }}$ postoperative and $10^{\text {th }}$ postoperative day haemoglobin/ haematocrit levels in the study group were $8.09 \mathrm{~g} / \mathrm{dL} / 23 \%$ and $8.92 \mathrm{~g} / \mathrm{dL} / 26 \%$ respectively [Table 1]. The mean preoperative haemoglobin and haematocrit level of control group was $11.02 \mathrm{~g} / \mathrm{dL}$ and $32 \%$. The mean $1^{\text {st }}$ post-operative and 10 postoperative day haemoglobin/ haematocrit levels were $10.8 \mathrm{~g} / \mathrm{dL} / 31 \%$ and $11.5 \mathrm{~g} / \mathrm{dL} / 34.02 \%$ respectively in the control group [Table-1]. The mean serum protein in the study group was $4.68 \mathrm{gm} \%$ with mean serum albumin and globulin was $2.5 \mathrm{gm} \%$ and $2.1 \mathrm{gm} \%$. In the control group, mean serum protein was $6.1 \mathrm{gm} \%$ with serum albumin and serum globulin level $3.6 \mathrm{gm} \%$ and $2.5 \mathrm{gm} \%$ respectively. Evaluation of graft-take done on the $10^{\text {th }}$ postoperative day revealed $100 \%$ graft take in $27 / 35(77.14 \%)$ patients among study group and 29/ 35 (82.85\%) patients among control group. $90-100 \%$ graft take was observed in 8 (22.8\%) patients among study group and in 6 (17.1\%) patients among control group [Table 2]. None of these patients required secondary surgery for their loss of graft and all healed spontaneously by conservative treatment. Graft take was almost in equal proportion in study and control group. Statistically there was no difference in the skin graft take in both groups $(\mathrm{P}>0.01)$.

Table 1: Mean Hb, PCV and serum protein in study group and control group

\begin{tabular}{|c|c|c|c|c|c|c|}
\hline \multirow[t]{2}{*}{ Parameters } & \multicolumn{3}{|c|}{ Study group } & \multicolumn{3}{|c|}{ Control group } \\
\hline & Mean $\mathrm{Hb}$ gm\% & Mean PCV & Mean serum protein & Mean Hb gm\% & Mean PCV & Mean serum protein \\
\hline Preoperative & 8.5 & 25.0 & & 10.92 & 32.0 & \\
\hline $1^{\text {st }}$ postoperative & 8.09 & 23.5 & 4.68 & 10.6 & 30.0 & 6.1 \\
\hline $10^{\text {th }}$ postoperative & 8.92 & 26.0 & & 11.0 & 33.02 & \\
\hline
\end{tabular}


Table 2: Mean thermal burn, raw area and graft take in both the groups

\begin{tabular}{lccc}
\hline & $\begin{array}{c}\text { Mean } \\
\text { thermal burn }\end{array}$ & $\begin{array}{c}\text { Mean raw } \\
\text { area }\end{array}$ & Graft take \\
\hline Study group & $20 \%$ & $7 \%$ & $100 \%$ in 27/35 (77.14\%) \\
& & & $90-100 \%$ in 8 (22.8\%) \\
Control group & $22 \%$ & $8 \%$ & $100 \%$ in 29/35 (82.85\%) \\
& & & $90-100 \%$ in 6 (17.1\%) \\
\hline
\end{tabular}

\section{DISCUSSION}

Various factors like anaemia, hypoproteinemia, infection, avitaminosis and prolonged use of steroids are known to cause poor wound healing; anaemia is frequently blamed because the haemoglobin is considered essential to maintain proper oxygenation..$^{[8]}$ Elective surgery is usually delayed to combat this deficiency, either by preoperative haematinics or by blood transfusions. The effect of anaemia on wound healing remains uncertain and the decision to transfuse blood is influenced by the $10 / 30$ empirical dictum that a patient with haemoglobin level $<10 \mathrm{gm} \%$ and haematocrit level $<30 \%$ requires blood transfusion. Despite various human and animal studies, no clinical consensus has been achieved on the absolute threshold for prophylactic transfusion in anaemic patients. However, studies on the physiology of anaemia have demonstrated that weakness at rest rarely occurs until haemoglobin level falls below $6 \mathrm{~g} / \mathrm{dL}$ and cardiovascular failure does not occur in normovolaemic, anaemic individuals until haemoglobin level falls below 3-4 g/dL or haematocrit drops below $10-12 \% .{ }^{[4]}$ Arterial blood carries $\mathrm{O}_{2}$ as oxy-haemoglobin in the red blood cells which, when exposed to low tension of oxygen in the wounded tissues, dissociates and oxygen leaves the blood stream and enters into the tissues. In the wounded tissue increased $\mathrm{CO}_{2}$ tension, decreased $\mathrm{O}_{2}$ tension, decreased velocity of blood, vasodilatation and increased temperature favour the dissociation of oxy-haemoglobin thus supplying more oxygen to the wounded tissue. Furthermore, in anaemia there is increased cardiac output, decreased blood viscosity and decreased peripheral resistance; all of which lead to increased perfusion thereby mitigating the ill effects of anaemia. ${ }^{[9,10]}$ As wounds consume less $\mathrm{O}_{2}$ in comparison to normal tissues, $\mathrm{PO}_{2}$ in wounded tissue can be maintained by increased perfusion with anaemic arterial blood despite its low oxygen content. Oxygen tension in the tissues depends upon diffusion across wound capillaries therefore the partial pressure of oxygen in the arterial blood $\left(\mathrm{PaO}_{2}\right)$ is a more important determinant for delivering oxygen in the tissues than the arterial oxygen content. ${ }^{[1-13]}$
In animal experimentation, haemoglobin as low as 2-3g/dL and PCV below 15 are compatible with normal development of tensile strength provided blood volume remains normal. ${ }^{[14]}$ This value seems to be very low for humans, therefore various investigators have tried to find out the minimal tolerable limit of haemoglobin below which wound healing will be impaired and blood transfusion will be necessary. Haemoglobin mass of an average $70 \mathrm{~kg}$ man is capable of delivering $1000 \mathrm{ml}$ of oxygen/minute. Since, oxygen-haemoglobin dissociation curve permits only $60 \%$ delivery of haemoglobin bound oxygen at a partial pressure of greater than $20 \mathrm{~mm}$ of $\mathrm{Hg}$. it is possible for a haemoglobin concentration of $6.5 \mathrm{~g} / \mathrm{dL}$ to deliver the required $260 \mathrm{ml}$ of oxygen/ minute. Further, there is increase in concentration of 2 , 3 diphosphoglycerate (2, 3 DPG) in red blood cells which favours the unloading of oxygen from haemoglobin to erythrocytes. ${ }^{[14]}$ These normal physiological responses to anaemia tend to restore the normal oxygen delivery to the tissues, but common sense dictates that at some point the oxygen carrying capacity is no longer sufficient to maintain $\mathrm{PO}_{2}$ in the capillaries and in the tissues then that level of anaemia would be detrimental for wound healing. This critical point is defined by various investigators in the range of haemoglobin $6 \mathrm{~g} / \mathrm{dL}$ and PCV $18 \%$ and this point is considered as the transfusion trigger. ${ }^{[15]}$

In our study, equal acceptance of graft in study and control group implies that anaemia and hypoproteinemia do not necessarily retard wound healing. In this study six (17.1\%) patients in the study group and four (11.4\%) in the control group were given colloids to maintain their blood volume during operation. None of the patients required blood transfusion during surgery or postoperative period. All the patients in the study group tolerated anaesthesia well and remained stable throughout the procedure. This shows that perioperative blood transfusion can be avoided in the surgical care of most patients who have normovolaemic anaemia without mortality and without significant morbidity. ${ }^{[16]}$

Interpolation of these data to surgical patients requires caution as coexisting cardiovascular or pulmonary disease may impair the compensatory response to anaemia. Moreover, increased metabolic activities and presence of fever increase the oxygen demand that may exceed the ability of the compensatory response, risking oxygen deprivation in vital organs. These data are specific for skin and subcutaneous wound healing and internal wound 
healing e.g. gastrointestinal anastomosis are different from the skin and subcutaneous tissue healing. ${ }^{[17]}$

We have used World Health Organisation (WHO) classification to categorize our patients. According to WHO classification anaemia is classified as mild when haemoglobin is between 9-11 gm\%, moderate when haemoglobin is 7-9 gm\% and severe in cases of haemoglobin less than $7 \mathrm{gm} \%{ }^{[18]}$

\section{CONCLUSION}

It is not mandatory to keep haemoglobin level at or $>10 \mathrm{~g} / \mathrm{dL}$ or PCV value at or $>30 \%$ for skin graft take, as mild to moderate anaemia per se does not cause any deleterious effect on wound healing; provided perfusion is maintained by adequate circulatory volume. Prophylactic transfusion to increase the oxygen carrying capacity of the blood for the purpose of wound healing is not indicated in asymptomatic anaemic patients (with haemoglobin levels greater than $6 \mathrm{~g} / \mathrm{dL}$ ) without significant cardiovascular or pulmonary disease. However, severe anaemia (haemoglobin $6 \mathrm{~g} / \mathrm{dL}$ ) needs to be corrected before surgery. In a patient with significant cardiovascular or pulmonary disease, transfusion policy must be individualized and should be based on evidence of supply dependent oxygen consumption. Avoiding unnecessary transfusions in this era of heightened awareness of their risks appears beneficial.

\section{REFERENCES}

1. Bains JW, Crawford DT, Ketcham AS. Effect of chronic anaemia on wound tensile strength: Correlation with blood volume, total red blood cell volume and proteins. Ann Surg 1966;164:243-6.

2. Madden JW, Arem AJ. Wound healing: Biological and clinical features. In: Sabiston DC, editor. Textbook of surgery, Vol 1. Philadelphia: WB Saunders; 1986. p. 207.

3. Polk HC Jr. Principles of preoperative preparation of the surgical patient. In: Sabiston DC, editor. Textbook of surgery, Vol 1.
Philadelphia: WB Saunders; 1986. p. 90.

4. Sittig KM, Deitch EA. Blood transfusion: For the thermally injured or for the doctor? J Trauma 1994;36:369-72.

5. Waymack JP, Alexander JW. Blood transfusion as an immunomudulator: A review. Microbiol Infect Dis 1986;9:177-83.

6. Kaplan J, Sar S. Diminished helper/suppressor lymphocyte Ratio and natural killer activity in repeated blood transfusions. Blood 1984;64:308-10.

7. Losee JE, Fox I, Hua LB, Cladis FP, Serletti JM. Transfusionfree pediatric burn surgery: Techniques and strategies. Ann Plast Surg 2005;54:165-71.

8. Chaudhary VK, Sarkar SK. A study of wound healing in iron deficiency anaemia. J Indian Med Assoc 1982;79:160-3.

9. Jonsson K, Jenson JA, Goodson WH 3rd, Scheuenstuhl H, West $\mathrm{J}$, Hopf HW, et al. Tissue oxygenation, anaemia, and perfusion in relation to wound healing in surgical patients. Ann Surg 1991;214:605-13.

10. Hopf HW, Hunt TK, West JM, Blomquist P, Goodson WH 3rd, Jensen JA, et al. Wound tissue oxygen tension predicts the risk of wound infection in surgical patients. Arch Surg 1997;132:9971005.

11. Whitney JD. Physiologic effect of tissue oxygenation on wound healing. Heart Lung 1989;18:466-76.

12. Kim KZ, Thompson DH, George TF 2nd, McQuillan PM, Kao TC. Effect of anaemia on survival of myocutaneous flaps in the pig. Otolaryngol Head Neck Surg 1994;111:509-12.

13. Hopf HW, Viele M, Watson JJ, Feiner J, Weiskopf R, Hunt TK, et al. Subcutaneous perfusion and oxygen during acute severe isovolumic hemodilution in healthy volunteers. Arch Surg 2000;135:1443-9.

14. Fong TP, Ko ST, Streczyn M, Westerman MP. Chronic anaemia, wound healing, and red cell 2, 3-diphosphoglycerate. Surgery 1976;79:218-23.

15. Levine E, Rosen A, Sehgal L, Gould S, Sehgal H, Moss G. Physiologic effects of acute anaemia: implications for a reduced transfusion trigger. Transfusion 1990;30:11-4.

16. Elechi EN, Elechi GN. Surgical management of patients with severe anaemia due to acute blood loss: A case for withholding perioperative blood transfusion. East Afr Med J 1995;72:343-4.

17. Buchmiller-Crair TL, Kim CS, Won NH, Chopourian HL, Shaw $\mathrm{KS}$, Fonkalsrud EW. Effect of acute anaemia on the healing of intestinal anastomoses in the rabbit. J Trauma 2001;51:363-8.

18. Hove LV, Schisano T, Brace L. Anaemia diagnosis, classification, and monitoring using cell-Dyn technology reviewed for the new millennium. Lab Hematol 2000;6:93-108.

Source of Support: Nil, Conflict of Interest: None declared. 